\title{
Application Research of CMM in Real Estate Entreprise Management
}

\author{
Linjie Chen \\ Nanjing Institute of Industry Technology \\ Nanjing 210046, China \\ E-mail:ngy001@163.com
}

\begin{abstract}
This paper analyzes the application feasibility of $\operatorname{CMM}$ (Capability Maturity Model for Software) in real estate business management, and builds the CMM of real estate enterprises, It includes five levels, which describes respectively the business management ability levels for real estate enterprises of different levels of maturity. Through the application of the model, it indicates that CMM can help continue upgrading the management capacity of real estate enterprises.
\end{abstract}

Keywords: CMM, Real Estate Enterprises, Management capacity, Continuous upgrading

In recent years, the Chinese real estate industry has seen a huge increase in price and a rapid growth in total quantity, However, there exists a problem of low management level, poor project operational capacity and lack of core competitiveness in the developmental mode of the Chinese real estate enterprises(Chen, Linjie, 2007, pp. 75-77). Although there are quite a few studies on how to improve management skills in the real estate enterprises, the research about continuing to enhance the capacity of the real estate business management is relatively rare and lack of interoperability. The paper attempts to use CMM (Capability Maturity Model) to study how the real estate enterprises can continue enhancing the management capacity.

\section{The necessity for real estate enterprises to enhance management capacity}

The level of corporate governance of the real estate business depends on management capacity, which includes advanced applications of management thought, increasing quality of management, and standardized management system applied and the resulting establishment of the various optimal distribution of resources. The necessity for real estate business to enhance management capacity lies in that it helps to realize the best allocation of resources in the real estate business, improve market competitiveness and achieve large-scale, intensive and scientific development. A real estate enterprise is in fact a "system integrator" or an organizer whose task is to integrate the elements such as capital, land, design, engineering, environment and other resources into product and to realize market value to maximum extend by means of demolition, planning, design, construction, marketing planning, advertising, marketing and other services. The core content of the work of real estate business management is to allocate rationally these resources and factors, mobilize the creativity of the staff in these enterprises and realize the maximization of the utility of enterprise resources. Many enterprises are managed extensively and in low level. The crux of the problem can be analyzed from a point of view of management, such as lack of internal coordination mechanisms, deficiency of a unified and effective cooperation mechanism, and estrangement between departments which can easily cause a conflict of interests; Another example is that inadequate attention is given to intangible cost factors such as time, trust and willingness to cooperate and a lot of manpower, material and financial resources will have to be used when problems arise, the hazards of which has an continuously enlarged "bullwhip effect". at the entire value chain (Guo, Jindan \& Wang Shan, 2008, pp. 103-106)For a single real estate project, to enhance the real estate business management capacity will help ensure the project quality, timeliness, as well as the effectiveness of the final product; For the synthesis development of a real estate enterprise, to do so can necessarily lead to the construction of competitive advantages such as cost, product quality, brand as well as the advantages of marketing services, and make real estate enterprises develop more classic products and create larger revenue, which allows the businesses to integrate existing resources better, optimize the development environment, and continue to improve their comprehensive competitiveness.

\section{The idea of CMM applies to the real estate business management skills to enhance}

\subsection{Capability Maturity Model and the main purpose}

CMM (Capability Maturity Model for Software, CMM) is designed in 1986 from Carnegie Mellon University's Software Engineering Institute. CMM provides a framework of step-by-step process of the evolution of the ability, the ladder is divided into five bands evolving level: the initial level, repeatable level, defined level, managed level and Optimize level. Each level provides a level of software process improvement, software implementation of each process 
depends on the level of some of the key process of the key domains of practice to achieve the Software Capability Maturity upgrading(Yang, Yiping, 2001, pp. 18-51). CMM's core is the idea of a continuous improving process, pointing out how a software organization to form a mature, there is the law of the software must process through the evolution of the way to improve, for the organization of software process improvement in a step-by-step and the steady development of the model. CMM can process assessment, capacity assessment, process improvement, and now is widely used in the software industry at home and abroad, many scholars tried to invoke this model to other areas, such as enterprise project management, enterprise marketing, enterprise knowledge management and University research management some of which have made some good results.

\subsection{CMM applies to management of real estate feasibility analysis}

Application of CMM key activity in real estate business management processes and software has a similar process. Real estate business management processes and software process are the surface activity of the two very different, but the nature of existence on the two shares many common features, reflected in: (1) Real estate business management activities of "process" characteristics. Real estate management activity is a process consisting of a variety of activities, including project SWOT analysis, environmental study area, the regional market positioning, market positioning project, the project early, refining the concept of project development, brand image and extend the project design VIS, building style and layout planning, unit design, construction such as construction, as well as more than 20 marketing aspects, which can be seen as a general process; At the same time, which in turn contains a number of separate "mini course", such as the early stage of the project also includes auction land, land acquisition, demolition and other activities. (2) The uniqueness of real estate activity process. The process of real estate development activity is highly intellectual activity, real estate developers are in fact "systems integrator", whose housing product is a product of intellectual activity. This software process is quite similar to the process of real estate development and even can be seen as a process of special software. (3) The object of the real estate business management - real estate development projects in a time of uncertainty, investment in high-risk and cost of non-controllable. Although the real estate business management at the development project is usually given the time constraints, but in actual operation, the developer often delays to submit products. And real estate development project cycle length, by the economic situation, market conditions, factors such as monetary policy impact, the project has a high-risk investment, cost is also relatively difficult to control. These are simultaneously faced by software process, it is these common features that make the real estate business management capability maturity model as a possible set up. Adapting CMM in the real estate business management, and the use of "continuous improvement" can be used to increase business management skills gradually.

\section{Real estate business management construction and connotation of the CMM}

\subsection{Construction of the real estate business management CMM}

The subject of real estate companies in building management capability maturity model, have made reference to the Capability Maturity Model, according to the real estate business management process itself, as well as the characteristics of China's real estate enterprise management mode of operation, builds business management Capability Maturity Model of real estate companies. From the level, the model is divided into the initial management class, the experience management class, system management class, fine management and innovation management class, each with different levels of management differences and maturity characteristics, as shown in figure(1).

Insert Figure 1 here

\subsection{Connotation of the real estate business management CMM}

Figure (1) we can see that the real estate business management CMM connotation in four aspects: First, the principle of "continual improvement", advocated by the real estate business management skills of "continuing to upgrade," this is a gradual adjustment in the management process rather than replaced. Second, coarse-to-fine continuous upgrading of management capacity is respected, and gradually realizes the standardization, the management of the process of refinement. From the original extensive management to institutionalized, standardized, to achieve quantified and standardized management, upgrade management capabilities are the symptoms. Third, focus on visualization of the extent of the management process and continuous improvement. From the initial "black-box method," the management of the entire process of the final visualization, visualization capabilities can continuously improve. Fourth, innovation is the highest goal. The model of the first few levels are continuing the process of standardization and institutionalization, but the most senior management to promote continuous innovation, the endless pursuit of innovation, this is the real estate business management capabilities of the highest goal.

\section{Real estate business management applications CMM}

Prior to the application of this model, the real estate business thought leadership must be unified, application-level in accordance with each set of key practice of the specific comparison, evaluation and improvement, see table (1).

Insert Table 1 here 


\subsection{The initial class}

At this level, the real estate business management processes are chaotic. In Real estate projects throughout the design, implementation, control and the various stages of decision-making tend to rely on the experiences of one or some of the personal. Although in certain projects or certain aspects of the project and primary sporadic use of project management, but plans are often inadequate implementation of the project to carry out random and unpredictable, the risk of projects is relatively large, business administration department only after the project was completed in order to assess whether the project successfully developed. At the initial level because of low management capacity, management will be more mistakes, but not to a major critical errors in the decision-making, project selection and positioning to the right, the project investment to science.

\subsection{Experience management class}

The real estate companies achieving this level have begun to take the initiative to the experience of successful projects in accordance with norms of various types of development projects, and in accordance with the experience of the successful implementation of norm-making process begin. This can effectively control a single project risk, improve the efficiency of the development, and expand the role of successful experience. But in the real estate business management there is not a unified management solution repeatable. At this time the key is to refine the successful experiences, especially the concept of successful project development, the promotion of the project group. Philosophy is the soul of real estate development, the core is constant development and customer value creation, providing the potential demand. Clearly want to face the market, carefully select projects, to do planning and design, architectural design, environmental landscape design integration, the use of high-tech products to develop real estate.

\subsection{System management class}

Implementation of development projects of different types of unified management. Explore different types of development projects and the definition of common and institutionalized. At the same time, formulate management model of different projects by different types of projects for their own characteristics. Formulate and implement a staff training program to ensure that managers are able to do the knowledge and skills requirements of jobs. At specific projects, may be to institutionalize the process of tailoring the standard. The cost of various projects, such as the cycle is under control and can track the quality of projects. At this time, the real estate business management has been able to achieve integrated management of development projects in different types of levels, and gradually the standardization of management processes. At this time the key is the management system, a mechanism should be flexible, the structure, mechanism, management system will affect the results, management capabilities are important guarantee. Therefore, it is necessary to improve the internal governance structure, remodeling business management system, set up to adapt to the real estate business enterprise development system. In the management model on knowledge management model to be used with the platform, and constantly improve the real estate project management process, improve the operational efficiency of the real estate business.

\subsection{Fine management class}

At this level, the different types of project management processes are integrated to quantify, and get to be understood and controlled. This means that the aim to quantify the process, many process enough data into the process database. Can realize the real estate business management process analysis and development of new processes and results, risks and the quality of the product must have the reliability of prediction and control. At this time the key is to optimize the flow of real estate business, it will be reengineered from the edge of the support of the core ability of the strategy finally starting to support and business-to-business value chain with pre-work (the investment decision-making and get to land), product research and development (real estate planning and design), construction projects (building construction), marketing (the promotion of real estate sales) and property services. ECRS analysis can be used from the Eliminate, Combine, Rearrange, Simplify four areas to maximize the value-added implementation proceeds. The refinement of the marketing services and refinement of cost management should be focused. Cost management to carry out a full range of analysis and research, know the cost of the action took place to seek to reduce costs due to a new breakthrough, such as with the scientific and technological progress, the proportion of building and installation costs downward trend, but housing-related planning, design, service such as the rising cost. It is necessary to act according to circumstances, the concept of innovation full cost management, cost control put into conscious acts of each person with management to create cost advantages(Chen, Linjie, 2008, pp. 36-39).

\subsection{Innovation Management class}

Model at this level is the most advanced, management innovation has become the most important characteristics of the process. How to optimize the management, prevention of possible defects, and explore the process of improving and promoting the success of management innovation are the most important activities. Layer at this level is endless. The real estate business management near this level of capability maturity level has been able to achieve all kinds of near-optimal allocation of resources, to ensure that the project greatly the quality and timeliness of the finish, as well as 
the effectiveness of the final product. At this time the key factors of production are to be carried out of the new combination, and continuously in real estate development activity in the introduction of new theories, new ideas, new processes, new methods, the new system, access to resources, the effect of the use of new and effective management of implementation the purpose of the resources available to increase the potential for wealth creation. Real estate business productivity used matrix forms of organization are the organizational structure, the productivity of new real estate business organizational forms are the use of modern information technology to set up a network-based forms of organization, can expand the real estate business and the division of responsibilities between external collaboration, use of social resources on the rapid development of the existing (Chen, Linjie, 2007, pp. 1-4).

4.6 Model test results

At the practical application of process management capabilities to enhance the process of continuous improvement is a continuous process, can not be achieved overnight, one-step, this is a long process. Moreover, different enterprises have different circumstances and different key factors, must be continuously enriched with experience, the key to the process of setting appropriate domain, the key aim of practice and maturity, so that the efficiency of real estate's largest enterprise management. Real estate business management skills to enhance the level of maturity are endless, enterprises should be committed to the continued application of the model and update the Capability Maturity goals and key processes such as domain. According to SEI statistics, software enterprises in the introduction of CMM management, labor productivity growth of $35 \%$ and the average error rate of an average reduction of $39 \%$. CMM management and real estate business the way it should be gradual, through the details, and partial improvement from quantitative to qualitative changes, real estate companies using CMM management, the effectiveness of its management should be a gradual move forward.

\section{Conclusion}

This article applies CMM to improve real estate enterprise management capabilities, builds a real estate business management CMM, the real estate business management skills will be graded situation and point out that the real estate business management skills to enhance the key factors to achieve the real estate business management skills so that The purpose of continuous improvement. However, over the real estate business management skills description CMM is the basic form of this model, it is necessary to improve this model, but also in-depth study in specific real estate business management on improving the basic process at all levels of the model on the domain and the key processes critical practice.

\section{References}

Chen, Linjie. (2007). Problems and Countermeasures in the Development of Chinese Medium and Small Real Estate Enterprises. Construction Economy, 5, pp. 75-77.

Chen, Linjie. (2007). Research on the Capability Evaluation of Independent Innovation of Chinese Real Estate Industry. Science Technology and Industry, 12, pp. 1-4.

Chen, Linjie. (2008). Study on China s Real Estate Industry Development Strategy in the Background of Rising Costs. Construction Economy, 7, pp. 36-39.

Guo, Jindan \& Wang, Shan. (2008). Multidimensional Tactics of Value Chain Optimization under the Strategic Perspective-Taking Real Estate Enterprise as the Example. Construction Economy, 4, pp. 103-106.

Yang, Yiping. (2001). Software Capability Maturity Model CMM method and its application. Beijing: Posts \& Telecom Press, pp. 18-51. 
Table 1. Real estate business management maturity characteristics of CMM key practice

\begin{tabular}{|c|c|c|c|c|c|}
\hline \multicolumn{2}{|c|}{ Maturity Level } & $\begin{array}{l}\text { Management } \\
\text { differences }\end{array}$ & Maturity characteristics & $\begin{array}{c}\text { Key Process Areas or key } \\
\text { practice }\end{array}$ & Remarks \\
\hline & $\begin{array}{l}\text { Innovation } \\
\text { management } \\
\text { class }\end{array}$ & $\begin{array}{l}\text { Optimize the } \\
\text { management } \\
\text { of change }\end{array}$ & $\begin{array}{l}\text { Improvement of the } \\
\text { management process has } \\
\text { been institutionalized, } \\
\text { achieve continuous } \\
\text { improvement }\end{array}$ & $\begin{array}{l}\text { The new combination from } \\
\text { factors of production } \\
\text { (productivity), the introduction } \\
\text { of new theories, new ideas, new } \\
\text { processes, new methods, the } \\
\text { new system, access to the new } \\
\text { results from resources using }\end{array}$ & $\begin{array}{l}\text { Continuous } \\
\text { Improvement }\end{array}$ \\
\hline & $\begin{array}{l}\text { Fine } \\
\text { management } \\
\text { class }\end{array}$ & $\begin{array}{l}\text { Organizational } \\
\text { capacity } \\
\text { management }\end{array}$ & $\begin{array}{l}\text { Quantitative management, } \\
\text { various types of projects } \\
\text { management process have } \\
\text { been integrated, quantified, } \\
\text { understood and controlled }\end{array}$ & $\begin{array}{l}\text { Optimize business processes in } \\
\text { real estate business and focused } \\
\text { the fine marketing service and } \\
\text { the fine cost management }\end{array}$ & $\begin{array}{l}\text { Depth to } \\
\text { Improvement }\end{array}$ \\
\hline & $\begin{array}{l}\text { System } \\
\text { management } \\
\text { class }\end{array}$ & $\begin{array}{l}\text { Process } \\
\text { Management }\end{array}$ & $\begin{array}{l}\text { Standards, various types of } \\
\text { project management process } \\
\text { can be defined and } \\
\text { understood and followed the } \\
\text { institutionalization of }\end{array}$ & $\begin{array}{l}\text { Management system, a } \\
\text { mechanism should be flexible } \\
\text { and adapt to set up businesses } \\
\text { in real estate enterprise } \\
\text { development system; the } \\
\text { platform for knowledge } \\
\text { management to be used to } \\
\text { management model, and } \\
\text { improve the management of the } \\
\text { process of real estate projects }\end{array}$ & $\begin{array}{l}\text { Steady } \\
\text { Improvement }\end{array}$ \\
\hline & $\begin{array}{l}\text { Experience } \\
\text { management } \\
\text { class }\end{array}$ & $\begin{array}{l}\text { Project } \\
\text { Management }\end{array}$ & $\begin{array}{l}\text { There is plan and discipline, } \\
\text { project management method } \\
\text { has been applied to similar } \\
\text { projects }\end{array}$ & $\begin{array}{l}\text { Refining the successful } \\
\text { experience of successful } \\
\text { projects such as the } \\
\text { development of ideas, which is } \\
\text { promoted to the project group }\end{array}$ & $\begin{array}{l}\text { Initial } \\
\text { Improvement }\end{array}$ \\
\hline & $\begin{array}{l}\text { The initial } \\
\text { class }\end{array}$ & $\begin{array}{l}\text { Chaotic } \\
\text { management }\end{array}$ & Random unplanned job & $\begin{array}{l}\text { Bad management, but the } \\
\text { project decision-making to be } \\
\text { accurate, such as project } \\
\text { location, project investment }\end{array}$ & $\begin{array}{l}\text { No } \\
\text { Improvement }\end{array}$ \\
\hline
\end{tabular}




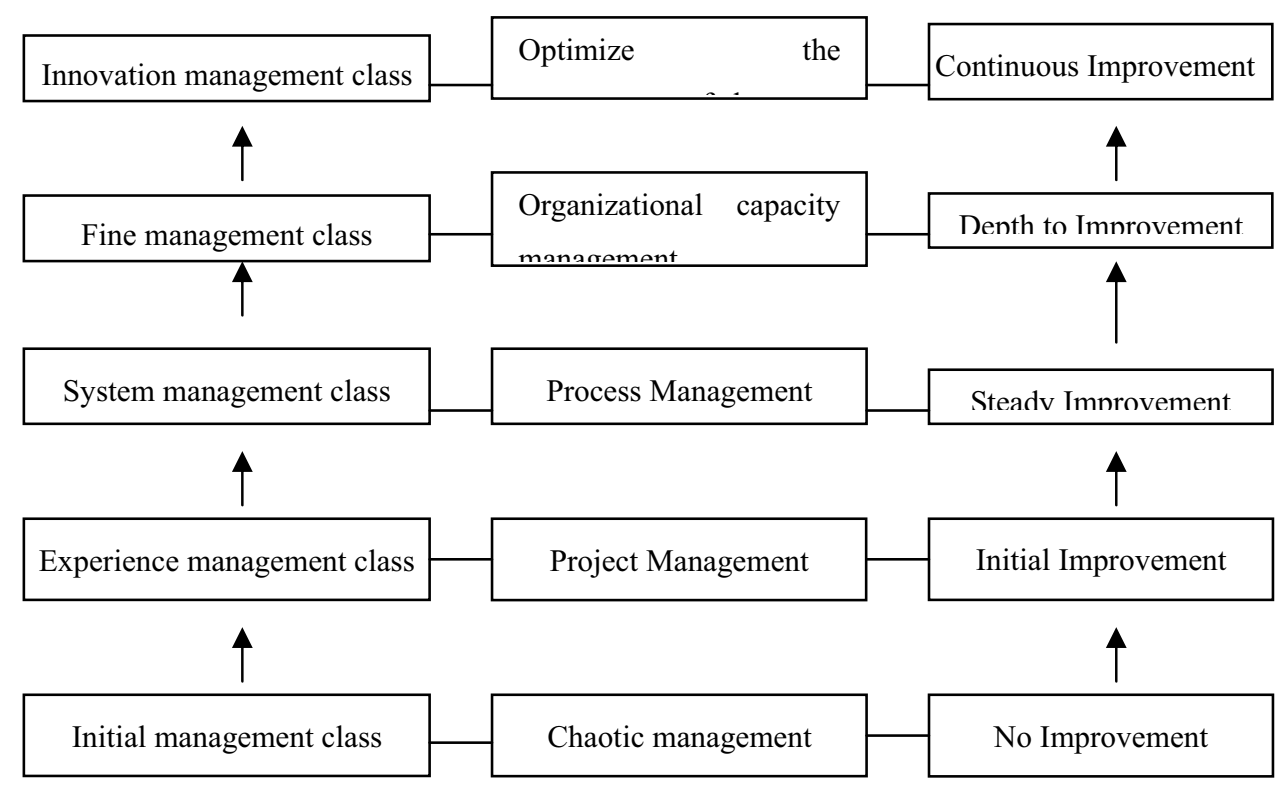

Figure 1. The CMM of real estate Enterprises management capacity 